DOI https://doi.org/10.17308/vsu.proc.law.2021.1/3318

\title{
ПРЕЮДИЦИЯ В УГОЛОВНОМ ПРОЦЕССЕ - ОБЪЕКТИВНОЕ ПРАВИЛО, СУБЪЕКТИВНО ПРИМЕНЯЕМОЕ (АНАЛИЗ ПРАКТИКИ СУДОВ ПЕРВОЙ И ВЫШЕСТОЯЩИХ ИНСТАНЦИЙ)
}

\author{
Г. В. Стародубова
}

Воронежский государственный университет

Поступила в редакцию 6 августа 2020 г.

\begin{abstract}
Аннотация: анализируется понилание и приленение института преюдииии в ходе производства по уголовному делу. Автор делает вывод об общей тендениии действия данного правила. Преюдициальность обстоятельств, установленных в ходе гражданского, арбитражного или административного судопроизводства, в уголовнол судопроизводстве обычно признается в тол случае, если они не противоречат той картине события, которая установлена при полощи уголовно-процессуальньх доказательств. Автор указывает на ошибки, которые были допущены при приленении в уголовнол судопроизводстве ст. 90 УПК РФ.
\end{abstract}

Ключевые слова: преюдииия, доказывание, правоприленение, уголовный процесс.

\begin{abstract}
: the article analyzes the understanding and application of the institute of prejudice in criminal process. The author makes a conclusion about the general trend of using of this rule. The presumption of circumstances established in the course of civil, arbitration or administrative proceedings is usually recognized in criminal proceedings if they do not contradict the event, which is established by the criminal procedural evidence. The author points out the mistakes made in cases where article 90 of the Criminal Procedure Code of the Russian Federation is applied in criminal process.
\end{abstract}

Key words: prejudice, proof, law enforcement, criminal process.

Уголовно-процессуальное доказывание нацелено на установление обстоятельств преступления, что дает возможность разрешить уголовное дело по существу, ответить на вопрос о виновности конкретного человека в нарушении запретов уголовного закона. Нормативные установления механизмов доказывания для следователя, дознавателя, судьи - объективная сущность, как и само преступление. Применение этих установлений связано с их осознанием, т. е. с человеческой способностью воспроизводить в мышлении действительность, от его сознания не зависящую. Именно ею обусловлено уголовно-процессуальное доказывание как особый порядок обоснования знания ${ }^{1}$.

Однако закон допускает и регулирует случаи отказа от получения в процессуальном порядке знания о преступлении или отдельных его

${ }^{1}$ См. более подробно: Стародубова $Г$. В. Установление истины в уголовном процессе. Воронеж, 2010. С. 11-21.

(C) Стародубова Г. В., 2021 


\section{Вестник ВГУ. Серия: Право}

аспектах. Такие случаи обусловлены, к примеру, нецелесообразностью поиска истины ввиду смерти обвиняемого, договоренностью об этом при примирении обвиняемого и потерпевшего и т. д. Кроме того, УПК РФ закрепляет ряд особых юридических способов установления обстоятельств, подлежащих доказыванию, когда правоприменитель без познавательных механизмов получает вывод об искомом факте. А. В. Смирнов о подобных ситуациях говорит, как о юридическом уровне доказывания, где действует особая, юридическая логика и применяются сугубо юридические средства, называемые формальными средствами доказывания ${ }^{2}$.

Одним из юридических способов установления обстоятельств, подлежащих доказыванию в ходе производства по уголовному делу, является применение правила о преюдиции (от лат. praejudicialis - относящийся к предыдущему судебному решению). Данное правило состоит в том, что с его нормативной легализацией на суд, рассматривающий дело, возлагается обязанность принять без какой-либо проверки и дополнительного исследования доказательств фракты, которые ранее установлены вступившим в законную силу судебным решением или приговором по другому делу. Преюдиция в уголовном процессе определяется ст. 90 УПК РФ как признание судом, прокурором, следователем, дознавателем без дополнительной проверки обстоятельств, установленных вступившим в законную силу приговором, за исключением приговора, постановленного судом в любом из вариантов особого порядка, либо иным вступившим в законную силу решением суда, принятым в рамках гражданского, арбитражного или административного судопроизводства, причем такие приговор или решение не могут предрешать виновность лиц, не участвовавших ранее в рассматриваемом уголовном деле.

В основе преюдиции лежат последствия вступления приговора или иного решения суда в законную силу - они становятся обязательными для всех органов государственной власти, органов местного самоуправления, общественных объединений, должностных лиц, иных фризических и юридических лиц.

Конституционный Суд РФ, характеризуя правовую природу данного правила, указал, что «преюдициальность служит средством поддержания непротиворечивости судебных актов и обеспечивает действие принципа

258 правовой определенности» ${ }^{3}$. В дополнение к этому использование механизма преюдиции позволяет экономить силы и средства, затрачиваемые на уголовное судопроизводство, поскольку из уже состоявшегося итогового судебного акта правоприменитель получает сведения, имеющие значение для дела, без собирания, проверки и оценки доказательств, т. е. без повторного доказывания отдельных обстоятельств.

${ }^{2}$ См.: Слирнов A. В. Формальные средства доказывания в уголовном праве и процессе. М., 2018. С. 27-28.

3 По делу о проверке конституционности положений статьи 90 Уголовно-процессуального кодекса Российской Федерации в связи с жалобой граждан В. Д. Власенко и Е. А. Власенко : постановление Конституционного Суда РФ от 21 декабря 2011 г. № 30-П // Вестник Конституционного Суда РФ. 2012. № 1. 
Нормативное закрепление преюдиции является ограничением действия принципа свободы оценки доказательств. Сведения о преступлении, имеющие значение для уголовного дела, которые содержатся во вступившем в силу приговоре или ином судебном решении, принимаются следователем, дознавателем, прокурором, судом как данность. Их использование не предполагает предварительного сопоставления с другими сведениями на предмет оценки их достоверности.

Однако сама природа человека, его творческие и аналитические способности de facto делают невозможным механическое применение данного правила без переработки сознанием правоприменителя и систематизации всей имеющейся информации. Дальнейшие действия будут зависеть от уровня его нравственности и целей, которые он перед собой ставит, занимая должности следователя, дознавателя, прокурора либо судьи. Один практик при наличии формальных условий применения преюдиции механически использует это правило. Иной, имея обоснованные сомнения в истинности знания об обстоятельствах, отраженного в судебных решениях, и достоверности сведений, на основе которых были сделаны соответствующие выводы, будет решать вопрос об определении пределов действия института преюдиции и возможности ее преодоления.

На эту проблему соотношения преюдиции и внутреннего убеждения лица, ведущего производство по делу и устанавливающего значимые для разрешения конкретного уголовного дела обстоятельства, указывается в научной литературе. Учеными-процессуалистами предлагаются разные варианты ее разрешения.

Так, Е. А. Доля, комментируя положения ст. 90 УПК РФ, отмечает, что если возникающие на практике противоречия между преюдициальным значением установленных по одному делу обстоятельств и внутренним убеждением прокуроров, следователей, дознавателей относительно этих же обстоятельств при производстве по другим уголовным делам не касаются виновности лиц, не участвовавших ранее в рассматриваемом уголовном деле, то эти противоречия должны разрешаться в пользу преюдиции 4 . В пользу примата ст. 90 УПК РФ над ст. 17 УПК РФ высказывается и Д. В. Зотов, указывая на конкуренцию отраслевой и институциональной нормы: предпочтение автор отдает последней в силу правила о преимуществе специальной нормы над общей 5 . На противоположных позициях - приоритета внутреннего убеждения - стоят В. А. Азаров и Д. М. Нурбаев, поскольку благодаря ему выбирается нужное направление поиска в достижении истины по уголовному делу ${ }^{6}$. Третий вариант

\footnotetext{
${ }^{4}$ См.: Научно-практический комментарий к Уголовно-процессуальному кодексу Российской Федерации / под общ. ред. В. М. Лебедева ; науч. ред. В. П. Божьев. 2-е изд., перераб. и доп. М., 2004. С. 222.

${ }^{5}$ См.: Зотов Д. В. Пределы доказывания в уголовном судопроизводстве. Воронеж, 2017. С. 161.

${ }^{6}$ См.: Азаров В. А., Нурбаев Д. М. Преюдиция и внутреннее убеждение при установлении истины в уголовном судопроизводстве // Известия Алтайского гос. ун-та. 2013. № 2-1. С. 79.
} 
решения проблемы связан с дополнительными правовыми механизмами. И. Л. Петрухин считает, что рассматриваемое противоречие должно быть разрешено в пользу принципа оценки доказательств по внутреннему убеждению судей, но при условии наличия «процедуры рассмотрения коллизионных судебных решений» ${ }^{7}$.

Конституционный Суд РФ в постановлении № 30-П высказывает свою позицию по этому вопросу: в качестве единого способа опровержения (преодоления) преюдиции во всех видах судопроизводства должен признаваться пересмотр судебных актов по вновь открывшимся обстоятельствам; опровержение преюдиции судебного акта, принятого в порядке гражданского судопроизводства, на основании одного лишь несогласия следователя и (или) суда, осуществляющего производство по уголовному делу, с выводами данного судебного акта, позволило бы преодолевать законную силу судебного решения в нарушение конституционного принципа презумпции невиновности и связанных с этим особенностей доказывания в уголовном процессе, игнорировать вытекающие из преюдиции обоснованные сомнения в виновности лица (если решение по гражданскому делу говорит в пользу его невиновности); преодоление вступивших в законную силу судебных решений административными органами не соответствует самой природе правосудия (п. 4.1, 4.2). Таким образом, главный орган конституционного контроля указал на жесткость межотраслевого института преюдиции итоговых решений суда в уголовном судопроизводстве.

Однако в том же постановлении Конституционный Суд РФ совершенно справедливо указывает, что «...предмет исследования в каждом виде судопроизводства имеет свои особенности, исходя из которых определяется не только компетентный суд, но и специфика процессуальных правил доказывания по соответствующим делам...» (п. 3). Уголовный процесс в этом ракурсе находится в привилегированном положении, поскольку за은 конодатель наделяет субъектов доказывания по уголовным делам наиболее широкими возможностями получения знания о преступлении. В связи с этим неопровержимой преюдиция может быть лишь внутри отрасли. Независимо от мнений и сомнений следователя, дознавателя, прокурора, судьи, каждый из них должен принимать без дополнительной

260 проверки обстоятельства, установленные вступившим в законную силу приговором суда по другому уголовному делу, рассмотренному в общем порядке с представлением и исследованием в судебном заседании всей совокупности доказательств. Именно внутри уголовного процесса нужно вести речь о преодолении преюдиции путем возобновления производства по уголовным делам, оконченным приговором, с которым связано применение рассматриваемого института. Ввиду равных возможностей для доказывания в уголовных производствах невозможно проигнорировать в одном результаты другого, чего нельзя сказать о результатах рассмотрения административных, гражданских, семейных и других дел.

7 Теория доказательств в советском уголовном процессе / отв. ред. Н. В. Жогин. Изд. 2-е, испр. и доп. М., 1973. С. 360. 
Особенности правил доказывания в иных, помимо уголовного, видах судопроизводства свидетельствуют о недостатках неопровержимой межотраслевой преюдиции. Собственно говоря, практика дает немало примеров такого понимания ст. 90 УПК РФ. Ее неприменяемость в конкретных уголовных делах судьи аргументируют именно цитатой из постановления Конституционного Суда РФ № 30-П об особенностях предмета исследования в разных видах судопроизводства и обусловленной этими правилами спецификой доказывания. Приведем пример.

Приговором Белгородского районного суда Белгородской области от 25 апреля 2018 г. П. осужден по ч. 4 ст. 159 УК РФ за совершение мошенничества группой лиц по предварительному сговору. В апелляционной жалобе защитник просил отменить данный приговор, указывая на ряд нарушений, допущенных судом первой инстанции при его постановлении, в том числе на то, что факт передачи денежных средств П. от продажи квартиры потерпевшей опровергнут решением суда, принятым по гражданскому делу и имеющим преюдициальное значение. Оставляя жалобу без удовлетворения, апелляционная инстанция Белгородского областного суда в апелляционном определении указала, что приведенное утверждение защитника необоснованно и подлежит отклонению, поскольку «как признание, так и отрицание преюдициального значения окончательных судебных решений не может быть абсолютным и имеет определенные, установленные процессуальным законом пределы. Пределы действия преюдициальности судебного решения объективно определяются тем, что установленные судом в рамках его предмета рассмотрения по делу факты в их правовой сущности могут иметь иное значение в качестве элемента предмета доказывания по другому делу, поскольку предметы доказывания в разных видах судопроизводства не совпадают, а суды в их исследовании ограничены своей компетенцией в рамках конкретного вида судопроизводства... Поскольку в уголовном судопроизводстве решается вопрос о виновности лица в совершении преступления и о его уголовном наказании, при этом уголовно-правовая квалификация действий (бездействия) лица определяется исключительно в рамках процедур, предусмотренных уголовно-процессуальным законом, и не может устанавливаться в иных видах судопроизводства, суд апелляционной инстанции оставляет без удовлетворения утверждения защитника о необходимости принятия без дополнительной проверки выводов, содержащихся в решении суда, принятом по гражданскому делу»

В ходе изучения судебной практики были выявлены и другие аналогичные решения вопроса о неприменении ст. 90 УПК РФ. Из этого следует вывод об общей тенденции действия правила о признании без дополнительной проверки обстоятельств, установленных в ходе гражданского, арбитражного или административного судопроизводства, в судопроизводстве уголовном: преюдициальность таких обстоятельств обычно признается в случае, если они не противоречат той картине про-

${ }^{8}$ Уголовное дело № 1-3/2018 // Архив Белгородского районного суда Белгородской области.

${ }^{9}$ К примеру, дело № 3/8-44/17 // Архив Центрального районного суда г. Воронежа. Есть описание подобных процессуальных ситуаций и в научных публикациях, например см.: Потетинов B. A. Как следователю преодолеть преюдициальное значение судебных актов, принятых вне уголовного судопроизводства // Рос. следователь. 2017. № 22. С. 27-30. 
исшествия, которая "написана» красками уголовно-процессуальных доказательств. В этих случаях противоречие между преюдицией и оценкой доказательств по внутреннему убеждению разрешается в пользу последнего. Преюдиция как объективное установление на практике применяется субъективно.

Анализ судебной практики позволил выявить некоторые ошибки в применении ст. 90 УПК РФ.

Суды необоснованно расширяют сфберу применения данной нормь, распространя ее на пролежуточные решения, принятые в период досудебного производства.

Так, Х. в порядке ст. 125 УПК РФ обратился в Коминтерновский районный суд г. Воронежа с жалобой, в которой просил отменить как незаконное и необоснованное постановление заместителя прокурора Коминтерновского района г. Воронежа об отмене постановления дознавателя Коминтерновского РОСП г. Воронежа и о возбуждении в отношении Х. уголовного дела. Постановлением Коминтерновского суда в удовлетворении жалобы было отказано, поскольку состоявшимся ранее и вступившим в законную силу постановлением того же суда Х. было отказано в удовлетворении аналогичной жалобы. Воронежский областной суд в апелляционном постановлении от 7 февраля 2017 г. № 22К-226/2017 указал на признание ранее вынесенным судебным решением указанного постановления заместителя прокурора законным и обоснованным и отсутствие оснований для его отмены. А это обстоятельство, по мнению суда апелляционной инстанции, согласно положениям ст. 90 УПК РФ, имеет преюдициальное значение и не требует дополнительной проверки ${ }^{10}$.

\section{Опишем еще одну ситуацию.}

28 августа 2015 г. в отношении С1 и С2 было возбуждено уголовное дело постановлением руководителя Бутурлиновского межрайонного следственного отдела СУСК РФ по Воронежской области. Данное постановление было обжаловано С1 в Бутурлиновский районный суд Воронежской области в порядке ст. 125

인 УПК РФ. Суд в удовлетворении жалобы отказал своим постановлением от 8 сентября 2015 г. Затем это же постановление о возбуждении уголовного дела было обжаловано С2 в Ленинский районный суд г. Воронежа, который постановлением от 7 июля 2016 г. производство по жалобе прекратил. Свое решение суд мотивировал тем, что жалоба С2 аналогична жалобе С1, а последняя уже рассматривалась Бутурлиновским районным судом и его постановлением оставлена

262 без удовлетворения, в связи с чем, в силу ст. 90 УПК РФ, отсутствуют основания для судебной проверки обжалуемого С2 процессуального решения. Воронежский областной суд постановлением № 22К-1792/2016 от 6 сентября 2016 г. удовлетворил апелляционную жалобу С2 на данное решение, поскольку с жалобой на постановление о возбуждении уголовного дела обратилось другое лицо, доводы которого подлежали проверке; ссылка на аналогичность содержания жалоб С1 и C2 правового значения не имеет. Однако при этом суд указал(!), что по «смыслу закона, постановление суда об отказе в удовлетворении жалобы на постановление о возбуждении уголовного дела может иметь преюдициальное значение только при рассмотрении аналогичной жалобы того же лица» ${ }^{11}$.

\footnotetext{
10 Дело № 3/10-168/16 // Архив Коминтерновского районного суда г. Воронежа.

${ }_{11}$ Дело № 3/10-161/16 // Архив Ленинского районного суда г. Воронежа.
} 
В приведенных примерах суд ссылается на преюдициальность юридической оценки законности и обоснованности обжалованного постановления, в то время как преюдициально установленными могут быть исключительно обстоятельства какого-либо события.

Возвращаясь к исследуемому вопросу, вновь обратимся к содержанию ст. 90 УПК РФ: законодатель четко указал на преюдициальность обстоятельств, установленных приговором, за исключением тех, которые стали результатом любого из сокращенных производств, а также решением суда, принятым в рамках гражданского, арбитражного или административного судопроизводства. В связи с этим Д. В. Зотов пишет: «Очевидно, что законодатель хотел указать на все итоговые акты (приговоры и решения), принимаемые Верховным Судом, судами общей юрисдикции и арбитражными судами» ${ }^{12}$.

Действительно, приговор является итоговым судебным решением. О других итоговых решениях по уголовным делам законодатель в данном случае не упоминает. Сам УПК РФ понимает их как приговоры, иные решения суда, вынесенные в ходе судебного разбирательства, которыми уголовное дело разрешается по существу (п. 53.2 ст. 5). Толкуя данную норму, Верховный Суд РФ еще больше расширяет ее содержание, указывая на определения или постановления суда, вынесением которых завершено производство по уголовному делу в отношении конкретного лица, как на итоговое ${ }^{13}$. Такое понимание вполне можно назвать обоснованным, поскольку в данных актах отражается результат процессуальной деятельности применительно к делу в целом либо применительно к конкретному подозреваемому либо обвиняемому. Но для затронутой темы важны те решения, которые вынесены по итогам исследования доказательств в ходе судебного следствия. Так, выносимые по формальным основаниям постановления о прекращении уголовного дела или уголовного преследования не содержат сведений об обстоятельствах, которые могли бы образовать преюдицию в другом деле. Соответственно законодатель совершенно логично указал в ст. 90 УПК РФ именно приговор, поскольку это решение выносится от имени Российской Федерации и основывается на непосредственно исследованных судом в судебном заседании доказательствах.

О преюдициальности сведений, содержащихся в промежуточных судебных решениях, недопустимо вести речь в принципе. Как отмечает А. С. Червоткин, «основная отличительная их особенность заключается в том, что в них не содержится окончательных выводов суда о достаточности доказательств, о виновности лица, о квалификации его действий,

12 Зотов Д. В. Указ. соч. С. 167.

${ }^{13}$ См. п. 4 постановления Пленума Верховного Суда РФ от 27 ноября 2012 г. № 26 (в ред. от 01.12.2015) «О применении норм Уголовно-процессуального кодекса Российской Федерации, регулирующих производство в суде апелляционной инстанции». Доступ из справ.-правовой системы «КонсультантПлюс». 


\section{Вестник ВГУ. Серия: Право}

о назначении ему наказания либо об освобождении от него» ${ }^{14}$. Именно вывод суда о достаточности доказательств для того, чтобы считать те или иные обстоятельства установленными, дает возможность назвать их преюдициальными. Промежуточные решения имеют другое предназначение и другие основания для их вынесения, не сопоставимые с институтом преюдиции.

Под решением суда, принятым в рамках гражданского, арбитражного или административного судопроизводства, в ст. 90 УПК РФ понимается также решение, которым дело разрешено по существу. Конституционный Суд РФ в «профильном» постановлении № 30-П неоднократно подчеркивает преюдициальную силу исключительно таких решений (п. 3.3, резолютивная часть).

Суды считают преюдициально установленнылии обстоятельства, содержашиеся в постановлениях по делам об адлинистративных правонарушениях.

Так, приговором Свердловского районного суда г. Белгорода от 26 марта 2019 г. Л. был признан невиновным в совершении преступления, предусмотренного ч. 3 , ст. 30 , п. «а», «Г» ч. 4 ст. 228.1 УК РФ в связи с отсутствием в деянии состава преступления. Среди представленных в судебном следствии доказательств имеются противоречащие друг другу протокол личного досмотра Л., проведенного 15 февраля 2018 г. в период с 22:45 до 23:20 в здании УНК УМВД России по Белгородской области, и постановление мирового судьи от 16 февраля 2018 г., которым Л. признан виновным в совершении административного правонарушения, предусмотренного ст. 20.20 КоАП РФ - невыполнение 15 февраля 2018 г. около 22:40 на улице у жилого дома законных требований сотрудника полиции о прохождении медицинского освидетельствования на состояние опьянения. Суд сослался на преюдициальное значение обстоятельств, установленных постановлением мирового судьи по делу об административном правонарушении,

-

은 показания сотрудников УНК, его проводивших. По результатам апелляционного пересмотра данный приговор был оставлен без изменений апелляционным определением Белгородского областного суда от 22 мая 2019 г. $^{15}$

Законодатель в ст. 90 УПК РФ указывает на преюдициальность обстоятельств, установленных решением суда, принятым в порядке адми-

264 нистративного судопроизводства. Административное судопроизводство и производство по делам об административных правонарушениях - не тождественные правовые явления, хотя, бесспорно, родственные, объединяемые родовым понятием «административный процесс». Последний, как отмечают Н. М. Конин и Е. И. Моторина, состоит из множества видов процесса, которые включают ряд производств, отличающихся друг от друга характером дел и регламентируемых специальными административнопроцессуальными нормами. Его видам являются, в том числе, админи-

${ }_{14}$ Червоткин А. С. Промежуточные судебные решения в уголовном судопроизводстве. М., 2018. С. 13.

${ }^{15}$ Уголовное дело № 1-8/2019 // Архив Свердловского районного суда г. Белгорода. 
стративно-юрисдикционный процесс, к которому относится производство по делам об административных правонарушениях, и административное судопроизводство ${ }^{16}$. В свою очередь содержанием административного судопроизводства является разрешение в судебном порядке споров о нарушенных субъективных публичных правах, свободах и интересах ${ }^{17}$. В ст. 90 УПК РФ законодатель очертил границы применения преюдиции решениями, принимаемыми в рамках уголовного, гражданского, арбитражного или административного судопроизводства. Производство по делам об административных правонарушениях к указанным категориям судопроизводства не относится.

В связи с этим, по меньшей мере, странно выглядит законопроект № 791911-7 «О внесении изменения в статью 90 Уголовно-процессуального кодекса Российской Федерации», согласно которому предлагается закрепить в качестве исключения из общей фрормулы преюдиции обстоятельства, установленные постановлением, принятым в соответствии с законодательством об административных правонарушениях ${ }^{18}$. Более того, согласно пояснительной записке к законопроекту, необходимость данных изменений объясняется негативной оценкой со стороны его автора статей Особенной части УК РФ, закрепляющих составы преступлений с так называемой административной преюдицией.

Термин «административная преюдиция» используется в связи с конструкцией отдельных составов преступлений - ст. 116.1, 151.1, 157, 158.1 и другие статьи УК РФ. Данные составы в качестве условия наступления уголовной ответственности предусматривают привлечение лица к административной ответственности и назначение соответствующего наказания. Административное наказание, которому подвергнуто лицо, является элементом объективной стороны этих составов преступлений ${ }^{19}$. Об использовании обстоятельств происшествия, установленных постановлением об административном правонарушении, речь не идет. Юридическое значение имеет только тот фракт, что подозреваемый либо обвиняемый подвергнут административно-деликтному преследованию за определенное административное правонарушение. Соответственно в том понимании, которое традиционно придается термину «преюдиция», данное его использование является некорректным, хотя словосочетание «административная преюдиция» прочно вошло в юридический лексикон, в том числе высших судебных органов. Так, Конституционный Суд РФ указывает на правомочность законодателя использовать институт уголов-

${ }^{16}$ См.: Конин Н. М., Маторина Е. И. Административное право : учеб. для бакалавриата и специалитета. 6-е изд., перераб. и доп. М., 2019. С. 144.

${ }^{17}$ См.: Общее административное право : учебник : в 2 ч. Ч. 2 : Административно-деликтное право (КоАП РФ). Административное судопроизводство (КАС РФ) / под ред. Ю. Н. Старилова. 2-е изд., пересмотр. и доп. Воронеж, 2017. С. 147.

${ }^{18}$ URL: https://sozd.duma.gov.ru/bill/791911-7 (дата обращения: 18.10.2020).

${ }^{19}$ См.: Комментарий к Уголовному кодексу Российской Федерации : в 4 т. (постатейный) / А. В. Бриллиантов [и др.] ; отв. ред. В. М. Лебедев. М., 2017. Т. 3 : Особенная часть. Доступ из справ.-правовой системы «КонсультантПлюс». 


\section{Вестник ВГУ. Серия: Право}

ной ответственности, когда противоправное деяние совершается лицом, имеющим специальную административную наказанность, используя в указанных целях так называемые составы преступлений с административной преюдицией ${ }^{20}$.

Судол придана преюдициальная сила доказательству, содержание которого отражено в протоколе судебного заседания по расслотрению другого уголовного дела.

Приговором мирового судьи судебного участка № 2 Новооскольского района Белгородской области от 26 мая 2015 г. было разрешено по существу уголовное дело частного обвинения в отношении А. (частный обвинитель У.). В описательно-мотивировочной части приговора мировой судья привела содержание показаний свидетеля, которая за давностью времени не смогла описать все обстоятельства произошедшего. Далее в приговоре со ссылкой на противоречия этих показаний указано об оглашении протокола судебного заседания от 23 января 2015 г. по уголовному делу частного обвинения в отношении У. (частный обвинитель А.) в части показаний этого же свидетеля. Мировым судьей отмечено, что «учитывая давность происшествия и преклонный возраст свидетеля, суд признает ее показания, данные в судебном заседании 23 января 2015 г., правдивыми, поскольку даны непосредственно после происшествия, и берет их в основу приговора в совокупности с другими доказательствами по делу согласно ст. 90 УПК РФ». Приведенный приговор отменен в кассационном порядке постановлением президиума Белгородского областного суда от 10 ноября 2015 г. № 4У-635/2015, в том числе в связи с тем, что «в приговоре судом придана преюдициальная сила протоколу судебного заседания, что в корне противоречит ст. 90 УПК РФ, раскрывающей объем и содержание понятия “преюдиция”»"21.

Действительно, законодатель говорит о преюдициальности обстоятельств, установленных приговором. Использование в таком качестве отдельных сведений об этих обстоятельствах (отдельных доказательств)

- недопустимо, поскольку разрешение уголовного дела по существу пред임 полагает оценку всей совокупности доказательств. Суд приходит к выводу об обстоятельствах преступления именно через систему взаимоподтверждающих, непротиворечивых, достоверных, относимых, допустимых сведений, облеченных в процессуальную фрорму.

Подводя итог анализу применения правила о преюдиции в уголовном процессе, сделаем некоторые выводы. Во-первых, законодательная модель неопровержимой межотраслевой преюдиции на практике реализуется фрактически по усмотрению следователя, дознавателя, судьи, осо-

${ }^{20}$ По делу о проверке конституционности положений статьи 212.1 Уголовного кодекса Российской Федерации в связи с жалобой гражданина И. И. Дадина : постановление Конституционного Суда РФ от 10 февраля 2017 г. № 2-П // Вестник Конституционного Суда РФ. 2017. № 2. См. также: Об отказе в принятии к рассмотрению жалобы гражданина Авраменко Владимира Николаевича на нарушение его конституционных прав статьей 264.1 Уголовного кодекса Российской Федерации : определение Конституционного Суда РФ от 27 июня 2017 г. № 1410-О. Доступ из справ.-правовой системы «КонсультантПлюс».

${ }^{21}$ Уголовное дело № 1-14/2015 // Архив судебного участка № 2 Новооскольского района Белгородской области. 
бенно когда речь идет о признании без дополнительной проверки обстоятельств, установленных решением суда, которое было принято по итогам иных видов судопроизводства, помимо уголовного. Преюдициальность таких обстоятельств обычно признается в случае, если они не противоречат фактам, установленным по уголовному делу. В этих случаях противоречие между преюдицией и оценкой доказательств по внутреннему убеждению разрешается в пользу последнего. Причиной тому являются разные механизмы доказывания в разных видах судопроизводств. Полагаем, что практика в данном случае обоснованно не признает неопровержимость межотраслевой преюдиции. Наиболее широкими возможностями получения сведений о событии преступления обладают субъекты доказывания по уголовным делам, в связи с чем преюдиция может быть неопровержимой лишь внутри отрасли. В свою очередь, это обусловливает потребность в изменении текста ст. 90 УПК РФ.

Во-вторых, анализ судебной практики показал, что применение ст. 90 УПК РФ не свободно от ошибок. Суды расширяли сферу применения данной нормы, распространяя ее на промежуточные решения, принятые в период досудебного производства, и ссылались на преюдициальность юридической оценки законности и обоснованности промежуточного решения, хотя преюдициально установленными могут быть исключительно обстоятельства какого-либо события. Суды оценивали как преюдициально установленные обстоятельства, содержащиеся в постановлениях по делам об административных правонарушениях. Доказательству, содержание которого отражено в протоколе судебного заседания по рассмотрению другого уголовного дела, придана преюдициальная сила. Думается, эти ошибки связаны со сложностью понимания сущности рассматриваемого института, с необходимостью иметь глубокие теоретико-правовые знания. Невнимательное отношение к тонкостям юридической конструкции в данном случае является причиной расширительного или неверного толкования правила о преюдиции.

Воронежский государственный университет

Стародубова Г. В., кандидат юридических наук, доцент, заведуюшая кафбедрой уголовного процесса

E-mail:gv_starodubova@mail.ru
Voronezh State University

Starodubova G. V., Candidate of Legal Sciences, Associate Professor, Head of the Criminal Process Department 